\title{
The BRICS Security Agenda and Prospects for the BRICS Ufa Summit
}

\section{Panova}

Victoria Panova - Associate professor, Department of International Relations and Foreign Policy of Russia, Moscow State Institute of International Relations; Chief Strategy Planning Advisor, NCR BRICS; 76 Vernadskogo Prospekt, 119454 Moscow, Russian Federation; E-mail: panova@nkibrics.ru

A rather recent phenomenon, the BRICS continues to provoke heated discussions on the prospects of the group and its sustainability as a community of like-minded actors. While common goals of reforming the international financial and economic architecture do not cause hesitation among observers, the security agenda for the BRICS occupies a grey area of uncertainty. As host of the BRICS in 2015-16, Russia sees as its main priority the transformation of the group from a loose forum into a full-fledged mechanism of economic and political coordination and cooperation. Peace and security issues may be, if not divisive, at least leading to limited to the lowest common denominator. This derives from a variety of factors - geographical and geopolitical positions, diverse political historic traditions, different international political status levels within the current political governance system, close economic and political ties, and complicated forms of cooperation and competition with the established western powers, as well as differences in understanding and promoting their own global ambitions and priorities. This article reviews the evolution of Russia's approach to the BRICS and its place within Russian foreign policy priorities, with attention given to political security, international law and global governance. Although several problems would receive only minor attention and are relevant to only some participants (such as fighting illegal drugs, maritime security or certain regional conflicts), others must be dealt with at the lowest common denominator (such as reform of the United Nations Security Council or non-proliferation), the BRICS continue to find new areas of possible cooperation and take small but sure steps toward creating a full-fledged mechanism of coordination among the five countries. Additional responsibility is vested in the BRICS, due to the fact that their cooperation and achievements in global political and economic governance reform are looked upon as an alternative way to domination of the advanced economies and a new model of equal and mutually beneficial cooperation by the majority of developing countries.

Key words: BRICS, global governance reform, peace and security agenda, regional crisis management, internet governance, cyber security, counter-terrorism, non-proliferation, sovereignty, multipolarity

\section{Introduction}

The BRICS group of Brazil, Russia, India, China and South Africa has become extremely fashionable lately. Russia, in assuming the chair of the summit in Ufa in July 2015, saw considerable surge of expert and political attention to the group's potential and its future. This fact is further boosted by the ongoing confrontation and divergence in world visions between Russia and the West, where as Russia sees BRICS and other emerging economies as natural allies in reforming the global order to make it more fair and inclusive and aware of interests of all of its players as opposed to the old rule makers. At the same time, the advanced economies of the Golden Billion still view the BRICS with varying degrees of skepticism and caution (depending on the political leaning and geographical location of the analyst, attitudes range from outright sarcasm with the stance of "what is the BRICS" to a moderate understanding of necessity to cooperate with the group but priority given to bilateral contacts with each of the five countries). 


\section{Common Goals for the BRICS}

It makes no sense to remember once again the origins of the BRICS club, but it is important to take a quick glance at the roots of the conceptual and strategic thinking about this cooperation scheme in Russia in order to understand what role for the BRICS the incoming chair is hoping for.

The acronym, which acquired a life of its own almost as soon as its founding father Jim O'Neill made it public, was not seen as anything more than a group of countries brought together exclusively based on economic terms. Russia's conceptual formation for diversifying policy away from an exclusively western club, which it strived to belong to during the 1990s, could be found with Yevgeny Primakov's ideas of Russia-India-China (RIC) triangle and enhanced cooperation with the Latin American countries, spurred by the Heiligendamm-L'Aquila Dialogue Process [see Panova, 2013b, a].

While many interests of the five countries remain at odds, a number of important convergences allow for the further intensification of cooperation and an ongoing search for common approaches.

To start with, all the BRICS countries are not happy with the rules of the existing world order. After the collapse of the Soviet Union and its socialist block, even though the world was not strictly bipolar even before that, the reality that everyone faced was to live in the westerncreated alternative, which provided for the possible cooptation of outsiders (either from former socialist community or developing countries of different types of government and economic system) on its own terms and in a system that generated primary preferences for the rule makers but not for everyone.

It is true that the primary concerns of all the BRICS countries lay within the domain of the economic and financial architecture, but it is no less true that political and economic governance areas are highly intertwined, which leads to a gradual realization of security issues being genuinely part of the agenda for BRICS deliberations.

Meanwhile, the five countries emphasized the fact that they are not willing for a revolution, but are uniting as a group of reformers for the benefit of the world as a whole. That said, they are unwilling to break the existing system or turn down the rules, which were worked out laboriously during the second half of the 20th century, especially those worked out collectively by all parties. That is why the BRICS countries firmly support international law and the rule of law as opposed to ad hoc actions. All five are so-called "sovereignty hawks," standing on a platform of sovereignty protection and non-interference in internal affairs as clearly provided in the United Nations Charter. The grouping also allows Russia to use benefits of network diplomacy, with the rule of not crossing any red lines, which stands in stark contrast to the "conditionality requirements typical of most Western institutions" [Roberts, 2009]. The BRICS is also a clear example of a democratic international arrangement, with countries of different types of political systems and governance, economic traditions, and cultural and civilizational attributes cooperate peacefully on an equal basis. This is a counter position to the postulate of only liberal democracies being full-fledged members of the world community and holding the right to a preferential voice in international communications. This view is reflected in the foreign policy concept of the Russian Federation.

The United Nations is seen by the BRICS as a central and only legitimate body ofglobal governance. All five countries share the assumption that only the UN Security Council (UNSC) is mandated with maintaining peace and security, which in turn leads to non-acceptance of unilateral measures taken in circumvention of that legitimate organ. As was rightly noted by Vyacheslav Nikonov [2013], head of the Russian National Committee on BRICS Research 
and deputy of the State Duma, "all five countries are interested in increasing to the maximum extent the role of the United Nations, in improving its mechanisms and in responding to global challenges and threats through multilateral diplomacy."

At the same time, the realization of the unique quality of the UN format pushes the BRICS into consistently trying to reform the organization. Appeals can be found in each BRICS summit declaration, with China and Russia underlining "the importance they attach to Brazil, India and South Africa's status and role in international affairs" including support for a "greater role in the UN" [BRICS, 2014]. Although observers try to point out that the two permanent members are not in a hurry to fight for a similarly permanent seat for the other three countries, it is clear that the whole concept of BRICS cooperation and its model of gradual change through reform and not revolution does not allow for hasty steps. Even though there is an ever growing realization in Russia that UNSC reform is an immediate necessity and primary consideration should be given to its partners from the emerging countries - first and foremost the BRICS - positions of the other Permanent Five members of the UNSC and lack of consensus among all the UN member-states do not make it a fait accompli.

More common ground for the BRICS, and for most of the other countries - especially those from the developing world - could be found in unequivocal support for multilateral world as opposed to unilateral approach. In fact, this position by its mere existence presents concern for the United States, which is to remain the only superpower and make sure all potential rivals are held back from rising. This position is reflected in different forms throughout the official U.S. National Security doctrines. At the start of this century, marked by George W. Bush becoming president, saw the document claiming the country possessing "unprecedented - and unequaled - strength and influence in the world," with the "great strength of this nation" to be used "to promote a balance of power that favors freedom" [United States, 2002]. Eight years later, the National Security Strategy adopted in the early years of Barack's Obama's administration states that "as we face multiple threats - from nations, nonstate actors, and failed states we will maintain the military superiority that has secured our country, and underpinned global security, for decades" [United States, 2010].

Official documents aside, this position was probably best described in an in-depth analysis produced by Stratfor Global Intelligence [2014] in 2011 and reprinted again in 2014 [Stratfor Global Intelligence, 2014]. Authors insightfully claim that although the United States is secure with regard to most of the world since it is "simply too geographically hostile to integration to pose significant threats," two regions could potentially cause concern: South America (or rather the Southern Cone divided among the four countries of Brazil, Argentina, Uruguay and Paraguay) and Eurasia (mostly its northern part consisting of European countries, Russia - or rather the former Soviet Union, and China). Given that the final goal of the United States is to ensure that none of these countries are united, which would present an eventual threat, its policies are directed at keeping those regions "divided among as many different (preferably mutually hostile) powers as possible" [Stratfor Global Intelligence, 2014]. This offers a perfect explanation for why the United States would not see the BRICS as a desirable phenomenon by its mere existence, the BRICS challenges core principles of U.S. strategy. ${ }^{1}$

Neither Russia nor any of the other four members of the BRICS is willing to confront the United States, or the North Atlantic Treaty Organization (NATO), or the so-called West. Their only goal within this cooperation scheme is to achieve a fairer world order, to multilateral ap-

${ }^{1}$ At present, the Euro-BRICS phenomenon is an insignificant movement with marginal forces in Europe supporting genuine cooperation on a uniting, as opposed to divising, bilateral platform between European countries and all the BRICS members. If this evolves into a serious process supported by European governments, it would present immediate threat to the Northern American hegemon. 
proaches and make their voices heard, and to ensure the overall recognition of the equality of different civilizational and developmental models. Washington is welcome to join those efforts. Unfortunately, a democratic equitable global architecture does not fit the strategic vision of the largest super-power, while the BRICS embrace a vision of a "multipolar and multi-civilizational world that will be based on the force of law rather than the law of force" [Nikonov, 2013].

\section{Russian Foreign Policy and the BRICS}

Even though it took a while for Russia to start implementing the concept of its foreign policy, what has started as a lagging Track Two policy track has gradually evolved into the prime high priority process. ${ }^{2}$ Russia first explicitly came up with the idea of diversification with Primakov's idea of the RIC triangle and multi-vector diplomacy in the mid 1990s. In the first half of that decade, Russia withdrew from various regions in the world, as opposed to the Soviet Union global presence, with its foreign policy concentrated in theory and practice on full integration with western countries and western-dominated institutions. With the unfavourable international developments and awakening of Russia, the 1997 Presidential Address to Federal Assembly marked a considerable deviation from the previous path, with the stated aims of diversification of foreign policy options. The most important goals included protecting Russian national interests avoiding confrontation, but based on strengthened stability and cooperation in international relations, as well as the establishment of a system of international relations based on the fact that "our world is multipolar, and there should be no domination of one centre of power," with the 21st-century world relying "less on military power but rather on the power of law" [Yeltsin, 1997].

The first practical manifestation of Russia's efforts to foster a multipolar world are found in the series of visits of Russian foreign minister Eugene Primakov to Latin America, which led to a number of agreements on "strategic partnership" with the leading states of the continent [Martunov, 2009].

Further on, the 2000 Concept of the Foreign Policy of the Russia Federation stated that Russia would "seek to achieve a multi-polar system of international relations" that reflect the reality of diverse world with differing interests and based on "mechanisms of collective resolution of key problems, on the priority of law and broad democratization" [Ministry of Foreign Affairs of the Russian Federation, 2000]. The next Foreign Policy Concept, in 2008, further stressed the strengthened economic potential of the "economic potential of the emerging global growth centers, inter alia, as a result of a more equal distribution of development resources due to liberalization of global markets" [Ministry of Foreign Affairs, 2008]. The logical conclusion is that economic power in those countries and regions is bound to lead to bigger political influence with further tendencies to polycentric world order.

Other issues raised in the 2008 concept concern the fact that "traditional cumbersome military and political alliances can no longer provide for counteracting the whole range of modern challenges and threats which are transnational in their nature," stipulating wider use of "network diplomacy" and flexible forms of multilateralism to protect national interests [Ministry of Foreign Affairs, 2008].

There is an acknowledgement in the official vision of the world development that "for the first time in the contemporary history that global competition is acquiring a civilizational dimension which suggests competition between different value systems and development models

${ }^{2}$ Such a situation was not only characteristic of Russia's cooperation with emerging economies. From the very start of Russia's existence as an independent state, its foreign policy placed cooperation in the post-Soviet space as a high priority, although not much was done in reality. 
within the framework of universal democratic and market economy principles" [Ministry of Foreign Affairs, 2008]. In the same document Russia also scolds the West for its "reaction to the prospect of loss ... of its monopoly in global processes" including the "continued political and psychological policy of 'containing' Russia. And, according to the document, the "unilateral action strategy leads to destabilization of international situation, provokes tensions and arms race, exacerbates interstate differences, stirs up ethnic and religious strife, endangers security of other States and fuels tensions in intercivilizational relations." Throughout the official discourse and documents there are also explicit statements about the central role of the UN, which, along with the multipolarity, sovereignty and the rule of law, are principles unequivocally shared by all the BRICS countries. Much attention is also attributed to the "cultural and civilizational diversity of the contemporary world."

As already mentioned, as the BRICS matured, the Russian government began to appreciate the group more. As president in 2006, Vladimir Putin promoted the idea of closer ties with Brazil, China and India, and it was during the presidency of Dmitry Medvedev that this club came into being at the leaders' level. Today the importance attached by the Russian elite to the BRICS cannot be underestimated.

One article written by the incoming President Putin [2012] read that Russia "would continue attaching priority to cooperation with the BRICS partners. This unique structure, created in 2006, most vividly symbolizes transformation from unipolarity to fairer world order." And then this view is reinforced by a statement by Russian foreign minister Sergey Lavrov [2012] the creation of the that BRICS proved to be "one of the most significant geopolitical events since the beginning of the new century."

According to its most recent Foreign Policy Concept, Russia attaches great significance to the "sustainable manageability of global development, which requires collective leadership by the major states of the world" - representative by geographic and civilizational aspects [Ministry of Foreign Affairs, 2013]. It is to provide for such sustainability that Russia will continue to expand cooperation "such formats as the Group of Twenty, BRICS, ... the Shanghai Cooperation Organization, the RIC (Russia, India and China) alongside other organizations and platforms for dialogue."

This mechanism is seen as a new model of global relations that overcomes the old barriers that divide East and West and North and South, and thus is bound to transform gradually into "multilateral strategic partnership embracing far-ranging issues of the global economy and politics" [Lavrov, 2012]. Russia is also ambitious in terms of the future for the BRICS, believing the idea of a "bridge" between North and South or it being only active within the scope of the South would essentially limit its capabilities as an independent actor in the international arena.

\section{BRICS Coordination on Peace and Security}

The initial idea behind the BRICS meetings at leaders' level grew from the necessity to coordinate the countries' positions within the G20, in response to the global financial and economic crisis. Even though the BRICS members never portrayed themselves as a political bloc and even less so as a security alliance, the purely economic and financial agenda speedily gave way to a whole range of political and global issues discussed actively by the five countries. Such discussions and cooperation were taking place both within the BRICS format and in multilateral platforms of other mechanisms such as the G20 and the UN.

The BRICS as an organization, as opposed to its current state as a forum or mechanism of informal cooperation among the leaders of five countries, is not very likely to evolve in the short 
term. The primary reason for this lies in the fact that the national economic development of each member (with the probably exception of Russia, which bid for high political stakes during the period of economic hardship and uncertainty with regards to further development, partly due to the structural mistakes of the last several decades and partly due to mounting external confrontational pressure) is an absolute priority over political agenda. Nevertheless over the short seven years since the BRICS came out as a full-fledged platform for global governance, political and security issues have gained considerable attention along with traditional economic, financial, but also global, social, humanitarian and cultural issues. Today all most acute issues on the political security agenda are present in BRICS deliberations: the traditional threats of conflict management and prevention, recurrences of unilateralist tendencies over multilateralism and central role of the UN, the substitution of international law by national legislation, to fighting terrorism, countering drug trafficking and transnational crime, maritime security and piracy, as well as the new challenges arising from weaponisation of space, cybercrime and internet governance. This list of issues, which is by no means exhaustive, enjoys varying degrees of support and converging approaches among the BRICS members. A few of the topics are briefly considered here, which does not mean this issues are more important or enjoy wider approval of the five countries than those not discussed in this article.

\section{Global Governance}

Two of the BRICS countries are permanent members of the UNSC, while the other three strive for a way to be represented on a permanent basis. Russia's position for a number of years has been to stress higher efficiency as the primary goal of the UNSC and a more representative character in order to take into account the changed realities of the world, and also to ensure a "prompt response to emerging crises and problems" [Ministry of Foreign Affairs, 2011]. Meanwhile, given the fact that no single model of reform enjoys overwhelming support, Moscow was taking a very cautious stance, suggesting it would be counterproductive to push any idea through, since it would "inevitably polarize the General Assembly." Instead it would continue its "diligent work on rapprochement of positions without introducing fake deadlines." Recent developments show that Russia has moved toward a much more sympathetic position towards the new candidates, especially its BRICS partners.

For quite some time, India and Brazil were considered part of a "G4" coalition along with Germany and Japan. With the shifts in political relations and cooperation schemes, there is an increased chance for a different group to become frontrunners in this race - the three countries of the BRICS. The problem that continues to hinder reform is that although there is consensus on the need of reform per se, the goals of the final outcome differ. So far BRICS have not dared to go further than repeat now and again the "need for a comprehensive reform of the UN, including its Security Council" and to reiterate the importance that China and Russia attach to the international status of the other three countries. The drama of the situation though, lies within the realm of limited possibilities of the BRICS. Although there is a growing realization that having all the five countries in the UNSC would be a positive achievement, the joint manifestation of the BRICS can lay the foundation of future reform but cannot accomplish the full construction of the edifice. This is visualized with regard to the deadlock over reforming the International Monetary Fund, which has far fewer opponents than reforming the UNSC.

Global governance reform and approaches showcase differences in the global standing of the five countries. While the ambitions of Brazil, India and South Africa on the global scale are largely limited by status upgrade within the UN, the other issues they are dealing with are mostly limited to regional significance (with the only exception the non-proliferation regime 
and India as a non-official nuclear club member). Although it is fair to say that of those three countries South Africa represents the most "regional" state. For South Africa, the BRICS is "an opportunity to project itself as the economic leader on the African continent and to capitalize on its association with a prestigious club of emerging economic powers" as opposed to striving for higher involvement in global governance issues [Wasserman, 2013, p. 110]. One could remember the efforts taken by Brazil and Turkey in 2009 with regard to the negotiations on the Iranian problem and the agreement reached with its government, but eventual failure due to the ultimate rejection by the western powers of this emerging powers initiative. According to one participant in the negotiations, "sanctions were imposed against Iran by the Security Council on the very day the so called Vienna Group submitted its comments on the Tehran Declaration to the IAEA, allowing no time for Iran to reply" [see Amorim, 2010, especially pp. 222-24].

Some experts see the manifestation of Brazil's global aspirations in the country's chairing the 2005 Review Conference on Nuclear Non-Proliferation Treaty and efforts to reintroduce the "thirteen steps to disarmament" in 2010 or its efforts in East Timor on peace restoration and development issues [Amorim, 2010; Chun, 2013, p. 50]. Many of Brazil's foreign policy efforts are directed at managing its regional stance. During its recent BRICS presidency, Brazil introduced Latin American outreach and it could be considered the main driving force behind UNASUR. However, unlike China or Russia, Brazil is not interested in reformulating the political rules of international relations, apart from its inclusion in UNSC with higher status for the newcomers.

According to some experts, India's foreign policy remains "confused and relatively vague" and although the government is largely "inward-looking," it realizes the impossibility of economic development without more intense engagement with the world [Chun, 2013, p. 94]. China's and Russia's ambitions are stretching to cover problems of global concern. This, in turn, presupposes if not diverging interests among the BRICS members, then a lack of interest of some members in comprehensive discussions of certain issues of global reach or differences in priorities for negotiating the topics to be dealt with. ${ }^{3}$

The BRICS governments, including Russia's, acknowledge that it is important to put forward consensual ideas at their meetings. Each knows the others' "red lines" that are not to be crossed. Even if only one differs in approach to a matter, there is no peer pressure, in order not to weaken the group. This does not mean that the five cannot disagree. The often different interests and incongruous attitudes do not prevent them from agreeing. On the contrary, exploring those divergences - counter to the hopes of many western analysts - lead to deeper understanding and allows to find ever more points of convergence.

\section{The Hot Spots}

Despite cooperation within the UN and on UN reform, there is not always full convergence among the five countries. Nevertheless, many observers as well as politicians themselves have acknowledged that the presence of all five countries on the UNSC in 2011 strengthened the dialogue on international peace and security. Peace and stability are seen as cornerstones for prosperous development in a predictable and safe world. The BRICS members do not see one other as a political bloc, less so as a military bloc, but they have gradually embraced an expanded political role. If the very first BRICS summit mentioned only one problem with a political and security flavour - the challenge of terrorism - the second meeting included discussions of the more problematic topic of Haiti, and the 2014 Fortaleza Declaration covers practically all the

${ }^{3}$ This conclusion is supported by the author's personal experience in the Track Two diplomacy discussions of experts and academia of the five countries since 2011. 
"hot spots" in all regions of the modern world, no matter how distant from any of the BRICS members either geographically or politically.

The club of emerging countries coordinated its position at the onset of the crises in Libya and Syria, and also took a common stance on deferring the vote on the role of the European Union in the UN General Assembly (UNGA) as well as on Cote d'Ivoire and Sudan.

In the case of Libya, the four BRIC countries together with Germany abstained from the vote on UNSC Resolution 1973 on the no-fly zone in 2011. South Africa adjusted its stance with its inclusion into the BRICS club that same year. After the BRICS Sanya Summit in 2011, Medvedev reiterated Russia's support for the common position on the exclusive use of political and diplomatic means and praised South African president Jacob Zuma for efforts taken as a head of African Union (AU) mission in the conflict. ${ }^{4}$

With the case of Syria, even with the differences in terms of voting for western-sponsored UNSC resolution on Syria in February 2012 (with Russia and China the only two countries of 15 to oppose it, coming up with a different draft that excluded threats of intervention and ensured the necessity for all political forces to be part of the negotiating process), essentially the position of all BRICS countries remained very much the same. The main point for the BRICS approach to Syria was an all-inclusive process for all political forces to call on all sides to stop the violence, not just President Bashar al-Assad. All the BRICS members strongly believe that process of political settlement should be led by the Syrians themselves, with no foreign intervention allowed. It was in part due to the BRICS's common position that Putin's initiative on the internationally supervised elimination of chemical arms in Syria was a success and helped to prevent foreign intervention into the country. Those favouring military options were facing not just the Russian position, but also their own public opinion and firm adherence to diplomatic means by major emerging economies, whose voice could no longer be easily ignored.

The five countries also managed to come up with non-conflictual approach to the Ukrainian crisis, counter to high hopes emanating from their western partners. India was the only BRICS country whose officials did not shy away from explicitly supporting Russia. Cautious and subtle reactions on the part of the rest of the group were understandable. China has problems of its own both in the security domain internally (Xingjiang-Uigur region) and externally (South and East China Seas), which makes it safest to appeal to the necessity of considering historical background before making judgements and while working out solutions, instead of offering explicit support for either side. A clear understanding of such an approach could be traced to the abstention vote taken by all the four countries during the UNGA resolution on Crimea in March 2014. Nevertheless, once again counter to the hopes of the western countries, none of the BRICS members was trying to suggest Russia was an international bête noire or pariah with regards to international politics as a whole or to that specific conflict. The Fortaleza Declaration demonstrated consensus conclusions on the need "for a comprehensive dialogue, the de-escalation of the conflict and restraint from all the actors involved, with a view to finding a peaceful political solution, in full compliance with the UN Charter and universally recognized human rights and fundamental freedoms," which in fact repeats the main points of Russia's stance on the Ukrainian crisis [BRICS, 2014].

\section{Terrorism}

The fight against terrorism was the first political security topic that was introduced onto the agenda of BRICS deliberations. In fact, it was already present in the very first BRIC summit

${ }^{4}$ In January 2012, Zuma issued an AU statement claiming that NATO had by far outstretched UNSC Resolution 1973 and should be held accountable for it. 
document issued at Yekaterinburg in 2009: the leaders not only strongly condemned "terrorism in all its forms and manifestations" and stressed absence of any possible justification for such acts, but also called for urgent adoption of the draft Comprehensive Convention against International Terrorism tabled at UNGA [BRIC, 2009b].

The second BRIC summit in Brasilia was aggravated by the fact that the two countries of the bloc suffered from terrorist attacks - Russia (a series of attacks in March 2010 in the Moscow metro stations of Lubyanka and Park Kultury, and two days later in the city of Kizlyar, with more attacks conducted in Dagestan and Ingushetia early April) and India (a series of attacks in February 2010 in Pune, with more tragedies occurring in March and early April in Kashmir). This prompted Brazil and China to "express their sympathy and solidarity with the people and Governments" of the other two countries [BRIC, 2009a].

Interestingly, next year, the BRICS countries (now with South Africa part of the group) introduced a new topic into the paragraph dealing with countering international terrorism. The whole statement remained intact from the previous two years with the only addition of importance of international information security and necessity to counter cybercrime [BRICS, 2011]. All in all, the challenge of terrorism received continuous but rather futile attention on the part of the BRICS. Each year, the leaders have repeated same mantra of condemnation and non-justification for terrorist activities, but lack their own ideas and initiatives to try to solve the problem, leaving it in general to the UN. ${ }^{5}$ At the 2014 Fortaleza Summit, apart from once again expressing grave concern, the leaders pointed to Syria as the main problem, given the high incidence of terrorist attacks.

Although terrorism presents varying degrees of danger for the BRICS countries, it is also true that this problem tends to expand. ${ }^{6}$ Thus, in 2013 the number of countries where more than 50 people were killed from terrorist attacks hit 24 , the highest point since the start of this century, out of the 162 countries measured all around the world [Institute for Economics and Peace, 2014, figure 4, p. 14]. If only recently South Africa and Brazil were seen as the countries with no terrorist attacks (11th and 116th respectively of 156 countries) and were largely probed for having territories where terrorist training activities took place, in 2014 their sad rankings went up [Starchuk, 2014]. Today, according to the Global Terrorism Index, India occupies sixth place on the scale of fatalities, Russia comes next in 11th place, China in 25th place, South Africa in 48th place and, finally, Brazil in 72nd place [Institute for Economics and Peace, 2014, figure 4, p. 8].

It remains true that instability and terrorism present the biggest challenge to the three countries of BRICS, which is why those questions have greater chances of coordination and practical steps in other formats where Russia, India and China are present, such as RIC and the SCO.

Thus, the SCO has the Shanghai convention to combat terrorism, separatism and extremism signed same year as the declaration of organization's establishment in 2001. Indeed that could be regarded as its founding document, with the task of fighting those evils seen as SCO's

\footnotetext{
${ }^{5}$ The Durban Summit was expressed novel support for the "implementation of the UN General Assembly Global Counter-Terrorism Strategy" [BRICS, 2013].

${ }^{6}$ BRICS members see "double standards" in the interpretation of causes for terrorist activities as unfair. China fully condemned the tragic attack against Charlie Hebdo in France, and appealed to western colleagues to avoid hypocrisy and double standards. Thus, the Chinese newspaper Global Times wrote that "condemnations of terror attacks in Russia and China are not as forthcoming from Western countries as opposed to the quick and unified reactions to the attack on Charlie Hebdo in France," continuing further that "even after China officially determines their terrorist nature, Western mainstream media puts quotation marks when describing these bloody assaults as "terrorist," saying that it is a claim of the Chinese government" [see BRICS Post, 2015].
} 
primary task. In order to fulfill those tasks, SCO leaders decided to create a permanent body the Regional Anti-Terrorist Structure - to allow for regular exchange and cooperation among relevant authorities. In 2012 the program of cooperation among SCO members on combat against terrorism, separatism and extremism was adopted for the years 2013-15, envisaging ways to increase the efficiency of such cooperation.

The 2015 SCO summit will be held right after the BRICS Summit in Ufa, and in a way will repeat the 2009 Yekaterinburg experience. The only difference is that India will likely be upgraded from observer status to full-fledged member of the SCO.

While the SCO includes Central Asian states, the RIC format is narrowed to only the biggest countries of Eurasia. The most recent meeting of the RIC foreign ministers proved their intent for closer cooperation in all areas of concern. The stakes are getting higher, with the withdrawal of the United States and its allies from Afghanistan. It is important for national security of the RIC to intensify collaboration, especially after the elections held in the country [TASS, 2015].

The fight against terrorism will be discussed with more efficacy in the SCO and RIC, but nevertheless BRICS should not be discarded at this point. Those five countries are affected by terrorist activities very differently: Russia, India and China find themselves in much more dangerous neighbourhoods. Nevertheless, the years that passed since the start of the new century have demonstrated that terrorism is not confined by borders and countries geographically distant from hot spots are not immune from international terrorism. Globalization does not only bring positive developments, but can inflict damage. This is clearly demonstrated by the general increase in the number and fatalities of terrorism attacks and South Africa and Brazil moving up the Global Terrorism Index. Another factor to take into account is that countries that seek a greater role and higher status in international relations should be ready for bigger responsibility in the world affairs. Fighting global evils is the responsibility that comes along.

\section{Internet Governance and Cyber Security}

Internet governance and cyber security bring the newest challenges, which are nevertheless precisely ones where BRICS could find themselves in one of most sustainable and effective discussions in political security domain. Their populations are heavily involved in internet use and those countries perform the highest growth rate of internet use, yet they remain somewhat on the "object" side of global internet governance. Today the BRICS contains $37.73 \%$ of internet users collectively [Internet Live Stats, 2014]. These countries also present considerable potential for further geometric growth of internet users. In India, out of a total population approaching 1.3 billion, $19.9 \%$ have internet access, compared to the U.S. with $86.75 \%$ of internet penetration with four times fewer people. ${ }^{7}$ While the other BRICS countries show much higher rates than India (46.03\% in China; $59.27 \%$ in Russia), their potential remains quite significant. According to Vladimir Orlov [2014, p. 2], the "total contribution of the internet sector to BRICS economies in 2013 topped $\$ 500$ bln, and yet the forecasts say it will double by 2015 . In the nearest future BRICS will represent the most numerous and active part of the 'digital society' of XXI century."

Of all the BRICS countries, Russia and China, joined by Brazil after the Snowden revelations, favour radical reform of current internet governance. Many experts point to the international telecommunications conference held in 2012 in Dubai under the auspices of the International Telecommunications Union (ITU) as a start of a "digital cold war," although discussions 2014].

${ }^{7}$ Average world internet penetration rate in 2014 amounted to 42,3\% [see Internet Live Stats, 
started earlier. At Dubai a coalition of countries (China, Russia, Iran, Gulf states - in all 89 countries) offered and later voted in favour of the renewed register of international telecommunications, which included definition of internet, the notion of sovereignty over internet and informational space, stronger role of the ITU in internet governance over privately held American corporation ICANN. The United States along with other Anglo-Saxon countries and European states (in all 55 countries) voted against the new register and presented those divergences as the fight between freedom and censorship [Demidov, 2013, pp. 77-79]. India and a small number of other countries abstained to avoid having to join any of the coalitions. ${ }^{8}$

Even though no unified position exists on all aspects of internet governance or approaches to cyber security, the five BRICS countries are definitely concerned with their own information security and cyber security. At their Durban Summit, the leaders reiterated their understanding of "the critical positive role the Internet plays globally in promoting economic, social and cultural development" [BRICS, 2013]. Thus, they clearly stated that "to contribute to and participate in a peaceful, secure, and open cyberspace" there should be secure "use of Information and Communication Technologies (ICTs) through universally accepted norms, standards and practices is of paramount importance." Two years earlier it was agreed that BRICS would start to realize the project to connect all five countries as well as some other states by transcontinental fibre-optic cables in order to achieve higher internet security and diversify the global network. The idea looked like a welcome and far-reaching step, which made it even more disappointing that with the plans of the internet cable in use in 2015, work has not yet even started, which to some extent undermines belief in the solid foundation of the BRICS.

At the Fortaleza Summit, which did not dwell on the realization of previous commitments, there was an increase in deliberations on internet governance and cyber security. The leaders stressed importance of working work out "a universal legally binding instrument" in the field of ICT with the UN having a central role [BRICS, 2014]. They saw as an absolute necessity "to preserve ICTs, particularly the Internet, as an instrument of peace and development and to prevent its use as a weapon." In order to continue joint efforts in this direction, they agreed to "establish a group of experts of BRICS member States which will elaborate practical proposals concerning major fields of cooperation and coordinate positions in international fora." Russia also suggested and won support from the other four countries to work out a BRICS agreement on cooperation in the field of internet governance and cyber security. While NETMundial, held in April 2014 in São Paolo was mentioned and its host was commended for the brilliant organization, its final documents were not cited in the Fortaleza Declaration due to disagreement of Russia with a number of its positions [Expert Center of E-Government, 2014]. After all, the BRICS is a consensus-based mechanism, and members do not exert unfriendly pressure on one other.

\section{Nuclear Non-proliferation}

The problem of nuclear disarmament has even more layers than UNSC reform, not only revealing divisions between "haves" and "have-nots," but also revealing the different approaches between "official members of the nuclear club" and "illegal possessors," those having potential for assured destruction and those with little capacity, etc.

As a signatory to the Non-Proliferation Treaty (NPT), Russia acknowledges the eventual goal of a world free of nuclear weapons, a position actively promoted by Brazil, or South Africa,

${ }^{8}$ India could be singled out as the biggest trouble maker and the only country that broke down recent WTO negotiations, which concerned its vital interests much more than the above-mentioned issue, to be able to remain in a comfortable "neutral" position. 
which voluntarily refused to possess nuclear weapons after ten years of having nuclear devices in 1989 and joined the NPT as a non-nuclear state in 1991. When it signed the bilateral START III treaty with the United States in 2010, Russia took a step toward that final goal, but further reductions are hampered by the unwillingness of the other "official nuclear club" countries to join in the negotiations while those in the "non-official nuclear club" are believed to have to accede to the NPT as non-nuclear states. Russia would not be willing to demolish its nuclear potential on a unilateral basis, as it still relies on its nuclear arsenal as a potential of containment. This holds even more true during the days of rising confrontation with western countries, when nuclear weapons are seen as a guarantee of sovereignty against possible encroachments.

Since there are more questions than answers in the existing non-proliferation regime, and all BRICS members take different approaches, this issue is covered on the principle of red lines not to be crossed. Russia prefers to concentrate within the group or on a bilateral level on smaller but equally important aspects, leading to the possibility of convergence of interests such as nuclear safety, initiation of talks on the treaty to prohibit the production of fissile materials for nuclear weapons and nuclear explosives at Geneva conference or the joint Russian-Chinese proposal on the treaty on non-weaponization of space [Interfax, 2012]. All BRICS countries cooperated intensively within the UN in order to promote this initiative, and took unified stand on non-use of force toward space objects [Medvedev, 2010].

\section{The Prospects for the BRICS}

The BRICS is no longer considered a young phenomenon. Recent statements describe aspects of decay and futility of the summits of these five countries as going through a middle-age crisis. It is right to move away from seeing BRICS as a global governance infant - it is no longer a novice in international affairs not knowing the rules of the game, or not able to influence those in order to claim its legitimate interests. The BRICS has already gone through the first cycle of meetings and has not only successfully survived the adjustment period, but has also managed to deepen interactions considerably on all levels of governmental and non-governmental cooperation, allowing for the creation of a rather solid dialogue matrix.

The BRICS has established itself as a building block, a firm foundation for the changing world architecture. It has achieved a lot over its short life, elevating in political and expert opinion of western advanced economies and its own public from neglect and patronizing irony to reluctant acknowledgement and cautious praise. It also is gradually growing from being a gathering of unhappy states deprived of desired higher status into a body with increasingly common interests and views on a wide range of economic and political issues. There is no need to underestimate divergences and often differing aims that those countries promote on the international agenda, and it is still to be seen if the BRICS will evolve into a solid and integrated cooperation mechanism, but results achieved so far within other multilateral institutions and in the bi- and pentalateral formats, as well as an already developed extensive structure of meetings at the levels of leaders, ministers, officials, experts, business, civil society and youth allow for rather optimistic prognosis for the BRICS as an important or at very least creative factor of world politics.

The minimum role attributed to this Big Five club in the future, in the worst-case scenario of its fameless break-up in the nearest future, would be the one as bulldozer for the lame economic and financial system with only few geriatric powers behind the helm. The five already brought about this "wind of change" to the forefront and that is an irreversible process, although it is still not clear how long, how painful and how disastrous this process would be. Joint and continuous efforts on the part of the BRICS are key to success of the reforms. Several BRICS 
institutions have already been born, such as the New Development Bank and the Contingent Reserve Arrangement. The acknowledgement of success and further convergence of BRICS countries and their attractiveness to the other countries in the developing and emerging world is a reaction on the part of the established Golden Billion. Recently provoked international crises and turbulence around some of the BRICS members and attempts to divide them by offering benefits to some members while penalizing unilaterally and thus illegally other members of the club demonstrate that the BRICS bloc is a reality in today's international architecture. Moreover, it is not only a reality; it is a more attractive alternative for the majority of the world and already presents a real power centre, fast approaching its goal of becoming rule takers as well as rule makers in the existing global edifice. This in turn allows for more hope for the realization of the best-case scenario with genuine coherence and convergence on vital international issues of the five countries eventually serving as a core group, attracting other countries by authority and soft power, and successfully leading to the claimed goal of more fair and democratic world order through evolution and consensus rather than chaos and revolution.

Thus, Russia's initiative has appeared to have played well, not only for the public good in the world politics and into the hands of emerging and developing countries, but also for facilitating change within Russian mentality, for centuries centred on Europe and then the EuroAtlantic as the only worthy partner or contender. Opening up the scope for real diversification and making real overtures to the other civilizations, other cultures and other continents will eventually boost economic performance in Russia and might lead to positive internal political dynamics.

The year 2015 is also of utmost importance for Russia due to the dramatic challenges it must face internally in economic and financial areas and externally in the political security field. The BRICS presidency presents an excellent opportunity for Russia to see the support of it partners in times of considerable difficulties, and also to demonstrate itself as a reliable partner and responsible global actor. During the Brazilian presidency, Dilma Rousseff personally put considerable efforts into the BRICS success and progress on most important issues. The announcement of the New Development Bank could be considered her personal success, as well as an undeniable achievement of the Brazilian team working on complicated negotiations and very divergent approaches and interests of the parties in this new endeavour. Russia's success as a host will be judged by its ability to achieve further institutionalization (deepening and expanding existing the links within the BRICS rather than turning the group into an organization) and tacit approval of other members of the goal of mechanism for full-fledged coordination. In order to achieve that goal, security, international law and global governance reform issues have to be tackled substantively, since this would allow the BRICS to claim one more area of international political domain where it has a voice and where its stand must be taken into account. The BRICS as a serious actor is needed by the majority of developing world in the Golden Billion-dominated international edifice in order to see the light at the end of the tunnel and show the possibility of peaceful change. It thus adds an extra burden on the five countries not just to meet and present a family photo to the world, but to achieve real results - not just once in a while, but with every meeting.

\section{References}

Amorim C. (2010) Brazilian foreign policy under President Lula (2003-2010): an overview. Revista Brasileira de Política Internacional 53, pp. 214-40. Available at: http://www.scielo.br/scielo.php?script=sci arttext\&pid=S0034-73292010000300013\&nrm=iso (accessed 2 May 2015). 
BRIC (2009a) "2nd BRIC summit of heads of state and government: joint statement of the BRIC countries' leaders.” Brasilia, 15 April. Available at: http://www.brics.utoronto.ca/docs/100415-leaders.html (accessed 2 May 2015).

BRIC (2009b) “Joint statement of the BRIC countries' leaders.” Yekaterinburg, 16 June. Available at: http:// www.brics.utoronto.ca/docs/090616-leaders.html (accessed 2 May 2015).

BRICS (2011) "Sanya declaration.” Sanya, 14 April. Available at: http://www.brics.utoronto.ca/docs/110414leaders.html (accessed 26 November 2014).

BRICS (2013) "BRICS and Africa: partnership for development, integration and industralisation." Durban, 27 March. Available at: http://www.brics.utoronto.ca/docs/130327-statement.html (accessed 26 November 2014).

BRICS (2014) "The 6th BRICS summit: Fortaleza declaration.” Fortaleza, Brazil, 15 July. Available at: http:// www.brics.utoronto.ca/docs/140715-leaders.html (accessed 26 November 2014).

BRICS Post (2015) Chinese media slams the West's hypcrisy in CharlieHebdo reaction. 9 January. Available at: http://thebricspost.com/chinese-media-slams-the-wests-hypocrisy-in-charliehebdo-reaction/\#.VVvsAVVV ikr (accessed 2 May 2015).

Chun K.H. (2013) The BRICs superpower challenge: foreign and security policy analysis. Farnham: Ashgate.

Demidov O.V. (2013) Mezhdunarodnaya bezopasnost' v oblasti ispolzovaniya ICT [International security in regional ICT use]. In: M. Kasenova, ed., Kiberbezopasnost' $i$ upravleniye internetom [Cybersecurity and internet governance]. Moscow: Statut, pp. 47-86. Available at: http://pircenter.org/media/content/ files/12/13969745490.pdf (accessed 2 May 2015).

Expert Center of E-Government (2014) "Strany BRICS prisnali centralnuyu rol mezhdunarodnogo prava $\mathrm{v}$ ispolzovanii interneta i borbe s kiberprestupleniyami." ["BRICS countries recognize the central role of international law in internet use and cybercrime."] 16 July. Available at: http://d-russia.ru/strany-brikspriznali-centralnuyu-rol-mezhdunarodnogo-prava-v-ispolzovanii-interneta-i-borbe-s-kiberprestupleniyami. html (accessed 2 May 2015).

Institute for Economics and Peace (2014) "Global Terrorism Index 2014: measuring and understanding the impact of terrorism." Sydney. Available at: http://economicsandpeace.org/wp-content/uploads/2011/09/ Terrorism-Index-Report.pdf (accessed 2 May 2015).

Interfax (2012) "Dalneishee razoruzhenie vriad li vozmozhno v formate tolko Rossii i SSHA." ["Further nuclear disarmament is hardly possible with only Russia and the US.”] Interview with Mikhail Ulyanov, 9 February. Available at: http://www.interfax.ru/230110 (accessed 2 May 2015).

Internet Live Stats (2014) “Internet users by country (2014).” Available at: http://www.internetlivestats.com/ internet-users-by-country/ (accessed 2 May 2015).

Lavrov S. (2012) BRICS: a new-generation forum with a global reach. In: J. Kirton and M. Larionova, eds., BRICS: the 2012 New Delhi Summit. London: Newsdesk. Available at: http://www.brics.utoronto.ca/newsdesk/ delhi/lavrov.html (accessed 2 May 2015).

Martunov B. (2009) Mnogopoliarny ili mnogotsivizationny mir? International Trends [Or a multicivilizational multipolar world ?] 7(3). Available at: http://www.intertrends.ru/twenty-first/014.htm (accessed 2 May 2015).

Medvedev D. (2010) "BRIC countries: common goals - common actions." Moscow, 13 April. Available at: http://en.kremlin.ru/events/president/news/7443 (accessed 2 May 2015).

Ministry of Foreign Affairs of the Russian Federation (2000) "The concept of the foreign policy of the Russian Federation.” Moscow, 28 June. Available at: http://www.mid.ru/Bl.nsf/arh/1EC8DC08180306614325699C00 3B5FF0?OpenDocument (accessed 2 May 2015).

Ministry of Foreign Affairs of the Russian Federation (2008) "The foreign policy concept of the Russian Federation.” Moscow, 12 July. Available at: http://archive.kremlin.ru/eng/text/docs/2008/07/204750.shtml (accessed 2 May 2015).

Ministry of Foreign Affairs of the Russian Federation (2011) "Russia's position at the 66th session of the UN General Assembly.” Moscow. Available at: http://www.mid.ru/bdomp/ns-dmo.nsf/66d11ad1c1bc0a7bc32576 790039c04a/4ddbc0829acf1f0ec32576790039eb6b!OpenDocument (accessed 2 May 2015). 
Ministry of Foreign Affairs of the Russian Federation (2013) "The concept of the foreign policy of the Russian Federation.” Moscow, 12 February. Available at: http://www.mid.ru/brp_4.nsf/0/76389FEC168189ED44257 B2E0039B16D (accessed 2 May 2015).

Nikonov V. (2013) "BRICS: analysing the security dimension." BRICS Information Centre. Available at: http://www.brics.utoronto.ca/newsdesk/durban/nikonov.html (accessed 2 May 2015).

Orlov V. A. (2014) Global internet governance as a new common agenda for BRICS states: proposals for shaping BRICS agenda for 2014-2015. Paper prepared for the BRICS Academic Forum, Rio de Janeiro, 16-19 March. Available at: http://www.pircenter.org/media/content/files/12/13951542070.pdf (accessed 2 May 2015).

Panova V. (2013a) BRICS: mesto Rossii v Gruppe, videnie i prakticheskie rezultaty, sovmestnaya deyatelnost' 'piaterki' v mnogostoronnih institutah. In: V. Nikonov and G. Toloraya, eds., V Strategiya Rossii v BRICS: celi i instrumenty. Moscow: RUDN.

Panova V. (2013b) BRICS: problemy vzaimodeistviya i potencial sotrudnichestva. Observer [BRICS: problems of interaction and the potential for cooperation] 153(276), p. 39. Available at: http://www.observer.materik.ru/ observer/N1_2013/039_053.pdf (accessed 2 May 2015).

Putin V. (2012) Rossija i meniyuschiysia mir [Russia and the changing world]. Moskovskikh novostyakh, 27 February. Available at: http://www.mn.ru/politics/20120227/312306749.html (accessed 2 May 2015).

Roberts C. (2009) Introduction. Polity forum: challengers or stakeholders? BRICs and the liberal world order. Polity 42(1), pp. 1-13. doi: 10.1057/pol.2009.20.

Starchuk M. V. (2014) BRICS: obschie i chastnye ugrozy mezhdunarodnoy bezopasnosti. International Organisations Research Journal [BRICS: general and specific threats to international security] 9(4), pp. 163-64. Available at: http://iorj.hse.ru/2014-9-4/140094266.html (accessed 2 May 2015).

Stratfor Global Intelligence (2014) “The geopolitics of the United States, Part 1: the inevitable empire.” 4 July. Available at: https://www.stratfor.com/analysis/geopolitics-united-states-part-1-inevitable-empire (accessed 2 May 2015).

TASS (2015) Russia, India, China stand for emerging countries' greater role in global economy. 2 February. Available at: http://tass.ru/en/economy/774963 (accessed 2 May 2015).

United States (2002) “The National Security Strategy of the United States.” Washington DC, 17 September. Available at: http://georgewbush-whitehouse.archives.gov/nsc/nss/2002/index.html (accessed 2 May 2015).

United States (2010) “The National Security Strategy.” Washington DC, May. Available at: http://www. whitehouse.gov/sites/default/files/rss_viewer/national_security_strategy.pdf (accessed 2 May 2015).

Wasserman H. (2013) South Africa and China as BRICS partners: media perspectives on geopolitical shifts. Journal of Asian and African Studies. doi: 10.1177/0021909613514191.

Yeltsin B. N. (1997) "Poriadok vo vlasti - poriadok v strane.” [“Order in power - order in the country."] Presidential address to the Federal Assembly of B.N. Yeltsin, 6 March. Available at: http://www.intelros. ru/2007/02/05/poslanie_prezidenta_rosii_borisa_elcina_federalnomu_sobraniju_rf_porjadok_vo_vlasti_ porjadok_v_strane_1997_god.html (accessed 2 May 2015). 